\title{
The Effects of Fermentable Dietary Fiber on Performance and Metabolism of Nile Tilapia (Oreochromis niloticus)
}

Patrícia Inês Mombach ${ }^{1}$

https://orcid.org/0000-0003-1356-9557

Taida Juliana Adorian²

https://orcid.org/0000-0002-8217-0067

Fernanda Rodrigues Goulart ${ }^{3^{*}}$

https://orcid.org/0000-0001-6096-0132
Marina Osmari Dalcin²

https://orcid.org/0000-0003-1922-1607

Cátia Aline Veiverberg ${ }^{3}$

https://orcid.org/0000-0002-8353-0319

Leila Picolli da Silva ${ }^{2}$

https://orcid.org/0000-0002-1721-094X

\section{Suziane Ghedini Martinelli ${ }^{4}$ \\ https://orcid.org/0000-0002-3416-3102}

${ }^{1}$ Federal Institute of Education, Science and Technology Farroupilha - Campus Santo Augusto, Rio Grande do Sul, Brazil; ${ }^{2} F e d e r a l$ University of Santa Maria, Department of Animal Science, Santa Maria, Rio Grande do Sul, Brazil;

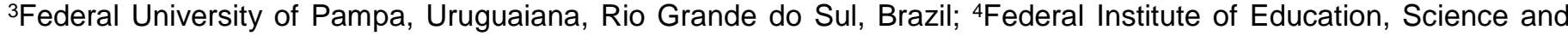
Technology Amazonas - Campus Lábrea, Lábrea, Amazonas, Brazil.

Received: 2019.07.03; Accepted: 2020.02.13.

${ }^{\star}$ Correspondence: fegoulart13@yahoo.com.br; Tel.: +55-55-996287111 (F.R.G)

\section{HIGHLIGHTS}

- Prebiotic effect of ecofriendly additives.

- New prebiotic to be studied to expand the options of these additives in aquaculture.

- Action of DFCP and DFL is equivalent to, or greater than, the commercial prebiotic.

- This study confirms the possibility of using the DFCP and DFL in fish nutrition.

Abstract: This study was conducted to evaluate the inclusion of new prebiotics in the diet on performance and metabolism (liver protein, glucose and glycogen) of Nile tilapia. For 60 days, 720 Nile tilapia (3.4 \pm 0.60 g) were maintained in 24 polypropylene tanks ( 280 liters). Fish were fed with experimental diets with addition of 2.5 and $5 \mathrm{~g} \mathrm{~kg}^{-1}$ of dietary fiber of citrus pulp (DFCP), dietary fiber of linseed (DFL) and Actigen $\circledast$. The experimental design was completely randomized with a 3x2 factorial arrangement. At the end of the period, there was higher final weight of tilapias fed on diets containing DFCP and DFL, and regardless of prebiotic, the best results in the final weight and length were observed for inclusion of $2.5 \mathrm{~g} \mathrm{~kg}^{-1}$. There was higher body protein deposition in tilapia fed on diets containing DFCP, without differences from those with inclusion of DFL. Total fat deposition was higher for the lowest level of inclusion $\left(2.5 \mathrm{~g} \mathrm{~kg}^{-1}\right)$. The digestive somatic index was higher for the diet with inclusion of DFCP, which did not differ from the diet with inclusion of Actigen $\circledast$. There were higher concentrations of liver glycogen in the diets containing DFCP and Actigen $\otimes$. Faced with the search for alternative growth promoters, this study confirms the possibility of using the new 
prebiotics (DFCP and DFL) in nutrition of Nile tilapia, because they showed efficiency equivalent to the prebiotic Actigen ${ }^{\circledR}$.

Keywords: additive; citrus pulp pectin; fish; linseed mucilage; nutrition.

\section{INTRODUCTION}

The per capita consumption of fish has increased sharply in recent decades, from $9.9 \mathrm{~kg}$ in 1960 to 19.2 $\mathrm{kg}$ in 2012. It was driven by a combination of population growth, income growth, urbanization, and more efficient distribution channels [1]. The consequent increase in production has led to greater susceptibility of fish to infectious diseases, usually controlled by the use of antibiotics as growth promoters. Currently, this practice is questionable because it poses considerable risks to human and animal health [2]. In this scenario, prebiotics are pointed out as an environmentally friendly alternative to prevent diseases and promote the growth of animals [3,4].

Prebiotics are non-digestible food ingredients that promote the growth and/or fermentative activity of beneficial bacteria in the gastrointestinal tract of the host [5], generating volatile fatty acids which may be used as a source of energy and promote beneficial changes in the metabolism, physiology and anatomy of the digestive tract of animals. Studies have indicated that prebiotics improve nutrient utilization and growth performance of several species of fish [6-10].

Normally, the formulation of commercial prebiotics is based on three major groups of oligosaccharides (fructooligosaccharides, mannanoligosaccharides and galactooligosaccharides), this limits the choice of best active ingredient, since the results will be influenced by type of prebiotic, levels of addition, time of use, characteristics of the animal, diet composition and farming environment [9]. It is believed that a greater diversity of prebiotic molecules can offer more options of ecofriendly additives, allowing better responses in fish performance.

In this scenario, pectic substances emerge as a promising alternative because of their differentiated chemical-structural composition, formed mostly of $\alpha$-D-(1,4)-galacturonic acid with a fraction of rhamnose and small amounts of other sugars [11]. Previous studies have reported that they promote the development of bifidobacteria, inhibition of harmful micro-organisms, reduction in the absorption of toxins in digestive tract and chelation of heavy metals [12]. In addition, obtaining pectic substances for use as prebiotic agents is industrially feasible, economically viable and environmentally correct, since the process can use fruit bagasse resulting from the extraction of juice as raw material.

Similarly, linseed mucilage, formed of two types of polysaccharides (neutral arabinoxylan and acidic pectic-like material) composed of arabinose, xylose, uronic acid, rhamnose, galactose and galacturonic acid [13], also arouses interest as an ecofriendly promoter. The use of the grain in natura can lead to antinutritional effects in fish and other animals, as a result of the substantial increase of viscosity of digesta, hindering the digestion and absorption of nutrients, which will reflect negatively on performance [14]. However, mucilage can be extracted from the grain of linseed, concentrated, and applied to rational levels, promoting beneficial effects and increasing the availability of prebiotic molecules in animal nutrition.

With the objective of increasing the options for ecofriendly products for fish farming, this study focused on the effects of new non-commercial prebiotics (DFCP and DFL) extracted from orange bagasse and grains of linseed, on performance and metabolism (liver protein, glucose and glycogen) of Nile tilapia (Oreochromis niloticus).

\section{MATERIAL AND METHODS}

\section{Obtaining the new prebiotics}

The residue resulting from the extraction of orange juice was washed in cold water and pressed manually, crushed in a multiprocessor, oven-dried $\left(55^{\circ} \mathrm{C}\right.$ for 24 hours) and ground in a $0.3 \mathrm{~mm}$ micro mill (Marconi, model MA-630/1, 27000rpm). Using the methodology described by Calliari [15], the pectic constituents with prebiotic potential were extracted from the residue in aqueous medium, at a concentration of $8 \%(\mathrm{w} /)$, at a temperature of $100 \stackrel{\circ}{\circ}$ for 1 hour. After cooling down, the solution was centrifuged $(3500 \mathrm{rpm} / 10 \mathrm{~min})$ and $93 \%$ ethanol was added to the supernatant at a $1: 1$ ratio. The solution was left to rest for $24 \mathrm{~h}$ at $5{ }^{\circ} \mathrm{C}$ for precipitation and separation of the pectic constituents. After recovery, the precipitate was dried at $55{ }^{\circ} \mathrm{C}$ for 48 hours in an air-circulation oven and ground to $0.3 \mathrm{~mm}$. The material resulting from this extraction was called DFCP. 
According to the methodology proposed by Goulart and coauthors [16], mucilage was extracted from whole grain of linseed (cultivar Normandy) in aqueous medium, at a concentration of $10 \%(\mathrm{w} / \mathrm{V})$, under temperature between 60 to $80^{\circ} \mathrm{C}$ and constant agitation, for 150 minutes. The supernatant was separated from the seeds, and $93 \%$ ethanol was added to final alcohol concentration of $75 \%$. After recovery, the precipitate was dried at $55^{\circ} \mathrm{C}$ for 48 hours in an air-circulation oven and ground to $0.3 \mathrm{~mm}$. The resulting material was called DFL.

\section{Diets}

The diets were isonutritional and formulated in accordance with the nutritional requirements for Nile tilapia (Oreochromis niloticus) fingerlings [17]. The six treatments consisted of diets supplemented with DFCP, DFL or Actigen ${ }^{\circledR}$ (commercial product based on mannanoligosaccharides) at two levels (2.5 or $5 \mathrm{~g}$ $\mathrm{kg}^{-1}$ ).

All the ingredients of the diets were weighed, mixed and pelleted. The pellets were dried in an aircirculation oven $\left(50^{\circ} \mathrm{C}\right)$ for $24 \mathrm{~h}$, and the size for consumption was adjusted in accordance with the development of the fish. Table 1 shows the ingredients and proximate composition of experimental diets.

Table 1. Ingredients and proximate composition of experimental diets provided to Nile tilapia.

\begin{tabular}{|c|c|c|c|c|c|c|}
\hline \multirow{3}{*}{ Ingredients $\left(\mathrm{g} \mathrm{kg}^{-1}\right)$} & \multicolumn{6}{|c|}{ Diets } \\
\hline & \multicolumn{2}{|c|}{ DFCP } & \multicolumn{2}{|c|}{ DFL } & \multicolumn{2}{|c|}{ Actigen $®$} \\
\hline & 2.5 & 5 & 2.5 & 5 & 2.5 & 5 \\
\hline Fish meal $^{1}$ & 300 & 300 & 300 & 300 & 300 & 300 \\
\hline Maize starch & 300 & 300 & 300 & 300 & 300 & 300 \\
\hline Cellulose & 57.5 & 55 & 57.5 & 55 & 57.5 & 55 \\
\hline SPC $60 \%{ }^{2}$ & 200 & 200 & 200 & 200 & 200 & 200 \\
\hline DFCP & 2.5 & 5 & 0 & 0 & 0 & 0 \\
\hline DFL & 0 & 0 & 2.5 & 5 & 0 & 0 \\
\hline Actigen $\circledast$ & 0 & 0 & 0 & 0 & 2.5 & 5 \\
\hline Melbond $\AA^{3}$ & 25 & 25 & 25 & 25 & 25 & 25 \\
\hline Soybean oil & 30 & 30 & 30 & 30 & 30 & 30 \\
\hline Vitamin and mineral mixture ${ }^{4}$ & 30 & 30 & 30 & 30 & 30 & 30 \\
\hline lodized sodium chloride & 5 & 5 & 5 & 5 & 5 & 5 \\
\hline Inert $^{5}$ & 50 & 50 & 50 & 50 & 50 & 50 \\
\hline $\mathrm{BHT}^{6}$ & 0.2 & 0.2 & 0.2 & 0.2 & 0.2 & 0.2 \\
\hline \multicolumn{7}{|c|}{ Diets composition $\left(\mathrm{g} \mathrm{kg}^{-1}\right)$} \\
\hline Moisture $^{7}$ & 46.8 & 44.4 & 40.8 & 44.6 & 44.5 & 43.8 \\
\hline Crude protein 7 & 292.6 & 303.1 & 300 & 298.7 & 295.3 & 300.9 \\
\hline Digestible energy $\left(\mathrm{MJ} \mathrm{kg}^{-1}\right)^{8}$ & 12.96 & 12.96 & 12.96 & 12.96 & 12.96 & 12.96 \\
\hline Crude fat ${ }^{7}$ & 73 & 74.9 & 76.5 & 73.5 & 73.8 & 75.3 \\
\hline Ash $^{7}$ & 161.1 & 160.2 & 162.8 & 161.2 & 159.3 & 160.2 \\
\hline Calcium ${ }^{9}$ & 16.9 & 16.9 & 16.9 & 16.9 & 16.9 & 16.9 \\
\hline Phosphor $^{9}$ & 6.7 & 6.7 & 6.7 & 6.7 & 6.7 & 6.7 \\
\hline Total dietary fiber ${ }^{7}$ & 187.2 & 200.2 & 185.7 & 185.6 & 201.1 & 200 \\
\hline
\end{tabular}

${ }^{1}$ Fish meal from Copisces Company, Paraná, RS. ${ }^{2}$ Soy protein concentrate, $60 \% \mathrm{CP} ;{ }^{3}$ Agglutinant calcium and magnesium lignosulfonates; ${ }^{4}$ Vitamin and mineral mixtures - composition $/ \mathrm{Kg}$ of product: Folic acid: $299.88 \mathrm{mg}$; Ascorbic acid: $15000.12 \mathrm{mg}$; Pantothenic acid: $3000.10 \mathrm{mg}$; Biotin: $0.06 \mathrm{mg}$; Niacin (B3): 9000.32 mg; Hill (B4): 103500.00 mg; Vitamin A: 1,000,000. IU; Vitamin B1: $1500.38 \mathrm{mg}$; Vitamin B2: $1500.00 \mathrm{mg}$; Vitamin B6: $1500.38 \mathrm{mg}$; Vitamin D3: 240000.00 IU; Vitamin E: 10000.00 mg; Vitamin K3: 400.00 mg; Inositol: 9999.92 mg; Iron: 6416.80 mg; Manganese: 8000.40 mg; Copper: 1000.00 mg; Zinc: 13999.50 mg; lodine: 45.36 mg; Cobalt: 60.06 mg; Selenium: 60.30 mg; Magnesium: $5.10 \mathrm{mg}$; Chloride: 2.30\%; Sulfur: 0.01\%; ${ }^{5}$ Sand; 6 Antioxidant butylated hydroxytoluene; ${ }^{7}$ Composition determination (Fisheries Laboratory/UFSM); ${ }^{8}$ Calculated digestible energy: [(Crude protein * $\left.5.65{ }^{*} 0.85\right)+\left(\right.$ Fat ${ }^{*} 9.4$ $\left.{ }^{*} 0.9\right)+($ Carbohydrates * $\left.4.15 * 0.7)\right][18] ;{ }^{9}$ Calculated values based on ingredients composition

\section{Biological trial}

The experiment was approved by the Animal Research Ethics Committee of the Federal University of Santa Maria (no. 23081.009051/2014-53) and conducted in the Laboratory of Fish Farming of this institution. 
Twenty-four experimental units were used (six treatments with four replications), with total useful volume of $280 \mathrm{~L}$, arranged in a water recirculation system, with mechanical and biological filtering. A total of 720 Nile tilapia fingerlings were distributed in the structure with mean initial weight of $3.4 \pm 0.60 \mathrm{~g}$ ( $30 \mathrm{fish} / \mathrm{tank}$ ), adapted for seven days prior to the start of the experiment. For 60 days of the experiment, the fish were fed three times a day ( $8 \mathrm{am}, 12: 30 \mathrm{pm}$ and $17 \mathrm{pm})$ up to apparent satiation.

\section{Water Quality}

Water quality in the farming system was controlled by cleaning the piping on a regular basis, siphoning the waste of each tank twice a day, one hour before feeding (7 am and $16 \mathrm{pm})$ and performing daily renewal of $10 \%$ of water from the system. Temperature was measured daily with a mercury thermometer $(26.7 \pm 1.46$ ${ }^{\circ} \mathrm{C}$ in the morning and $27.05 \pm 1.34 \stackrel{\circ}{\circ} \mathrm{C}$ in the afternoon). The following parameters were were measured weekly with colorimetric kits (Alfa-Tecnoquímica): dissolved oxygen (7.24 $\left.\pm 0.73 \mathrm{mg} \mathrm{L}^{-1}\right), \mathrm{pH}(7.63 \pm 0.35)$, alkalinity $\left(46 \pm 12.47 \mathrm{mg} \mathrm{CaCO} / \mathrm{L}^{-1}\right)$, hardness $\left(31.5 \pm 23: 46 \mathrm{mg} \mathrm{CaCO}^{-1} \mathrm{~L}^{-1}\right)$, ammonia $\left(0.270 .18 \mathrm{mg} \mathrm{L}^{-1}\right)$ and nitrite $\left(0.14 \pm 0.20 \mathrm{mg} \mathrm{L}^{-1}\right)$. For the purpose of analysis, water was collected at the entrance to the biological filter.

\section{Data collection and assessed variables}

At 60 days after the beginning of the experiments, data collection was performed in order to evaluate fish performance. Fish biometry was performed after $12 \mathrm{~h}$ fasting and sedation with benzocaine (Henrifarma $\AA$ Produtos Químicos e Farmacêuticos LTDA; Cambuci, SP, Brazil) at a concentration of $100 \mathrm{mg} \mathrm{L}^{-1}$. Eight fish/treatment were euthanized by an overdose of benzocaine $\left(250 \mathrm{mg} \mathrm{L}^{-1}\right)$ for the analysis of whole fish composition. Eight fish/treatment were euthanized by an overdose of benzocaine $\left(250 \mathrm{mg} \mathrm{L}^{-1}\right)$ for the calculation of carcass yield and digestive indices; fish liver was also collected, which was frozen $\left(-18{ }^{\circ} \mathrm{C}\right)$ for further metabolic analysis.

Zootechnical parameters: Based on the weight and length measurements, the following data were gathered: initial weight: IW (g); final weight: FW (g); total length: TL (cm); feed intake: FI (g); apparent feed conversion: AFC; protein efficiency ratio: PER; specific growth rate $(\% /$ day $)$ : SGR $=$ [(In final weight - In initial weight)/days] * 100 , where: In = neperian logarithm.

Biometric data collected at 60 days after the beginning of the experiment were used for calculating: carcass yield (\%): $\mathrm{CY}=$ (gutted fish weight/whole fish weight) ${ }^{*} 100$; digestive somatic index (\%): DSI= (digestive tract weight /whole fish weight) ${ }^{*} 100$; hepatosomatic index (\%): HSI= (liver weight/whole fish weight ${ }^{*} 100$; visceral fat index (\%): VFI= (visceral fat weight $/$ whole fish weight) ${ }^{*} 100$.

Body Retention of nutrients: Whole fish samples were analyzed for crude protein [19] and fat [20] for subsequent calculation of body retention of these nutrients with the following equations [21]:

- Total Deposited Crude Protein (TDCP): [Wf * (\%BCPf/ 100)] - [Wi * (\%PBCi/ 100)];

- Total Deposited Fat (TDF): [Wf * (\%BFf/ 100)] - (Wi * [\%BFi/ 100)];

Where: $\mathrm{Wf}=$ final weight; $\mathrm{Wi}=$ initial weight; $\mathrm{BCPf}=$ final body crude protein; $\mathrm{BCP}=$ initial body crude protein; $\mathrm{BFf}=$ final body fat; $\mathrm{BFi}=$ initial body fat.

Metabolic parameters: In the liver, measurements were made of total protein [22], glucose and glycogen [23] levels.

\section{Experimental design and statistical analysis}

The experimental design was completely randomized with a $3 \times 2$ factorial arrangement. The results were submitted to the normality test and analysis of variance ( 2 paths: prebiotics $x$ levels). The means were compared by Duncan's multiple range test at $5 \%$ level of significance.

\section{RESULTS}

\section{Zootechnical parameters and body retention of nutrients}

Final weight (FW) was higher for tilapia fed on diets containing non-commercial prebiotics (DFCP and DFL) when compared with the commercial product (Table 2). Regardless of prebiotic, the best results for FW $(W=0.04)$ and total length $(T L)(P=0.03)$ were observed for $2.5 \mathrm{~g} \mathrm{~kg}^{-1}$ of inclusion (Table 2). The action of the tested prebiotics showed equivalence for initial weight (IW), total length (TL), feed intake (FI), protein efficiency ratio (PER) and specific growth rate (SGR). 
Table 2. Growth parameters for Nile tilapia fingerlings fed on diets containing DFCP, DFL or Actigen 1.

\begin{tabular}{|c|c|c|c|c|c|c|c|}
\hline Factor/Variables ${ }^{2}$ & IW (g) & $\mathrm{FW}(\mathrm{g})$ & $\mathrm{TL}(\mathrm{cm})$ & $\mathrm{FI}(\mathrm{g})$ & AFC & PER & $\begin{array}{c}\text { SGR ( \% } \\
\text { /day) }\end{array}$ \\
\hline \multicolumn{8}{|l|}{ Source $^{3}$} \\
\hline DFCP & $3,37 \pm 0.0$ & $62.31 \pm 12.7^{a}$ & $14.14 \pm 1.0$ & $453.04 \pm 5.8$ & $1.1 \pm 0.0$ & $1,07 \pm 0.0$ & $4.86 \pm 0.1$ \\
\hline DFL & $3,37 \pm 0.0$ & $62.30 \pm 12.6^{a}$ & $14.16 \pm 0.9$ & $456.52 \pm 1.8$ & $1.1 \pm 0.0$ & $1,07 \pm 0.0$ & $4.86 \pm 0.1$ \\
\hline Actigen $®$ & $3,37 \pm 0.0$ & $59.73 \pm 12.5^{\mathrm{b}}$ & $14.00 \pm 0.9$ & $454.36 \pm 5.5$ & $1.1 \pm 0.0$ & $1,03 \pm 0.1$ & $4.79 \pm 0.1$ \\
\hline \multicolumn{8}{|l|}{ Level $\left(\mathrm{g} \mathrm{kg}^{-1}\right)^{4}$} \\
\hline 2.5 & $3,38 \pm 0.0$ & $62.48 \pm 11.9^{a}$ & $14.18 \pm 0.9^{a}$ & $455.18 \pm 5.1$ & $1.1 \pm 0.0$ & $1,06 \pm 0.1$ & $4.86 \pm 0.1$ \\
\hline 5 & $3,36 \pm 0.0$ & $60.41 \pm 13.2^{b}$ & $14.01 \pm 1.0^{\mathrm{b}}$ & $454.10 \pm 4.6$ & $1.1 \pm 0.0$ & $1,06 \pm 0.0$ & $4.82 \pm 0.1$ \\
\hline
\end{tabular}

${ }_{1}^{1}$ Values were expressed as mean \pm standard deviation. ${ }^{2}$ Variables - IW: initial weight; FW: final weight; TL: total length; FI: feed intake; AFC: apparent feed conversion; PER: protein efficiency ratio; SGR: specific growth rate. ${ }^{3}$ Means followed by different letters in the column, differ statistically by Duncan's test $(p<0.05) .{ }^{4}$ Means followed by different letters in the column, differ statistically by Student's t-test $(p<0.05)$. NS: non-significant $(p>0.05)$.

Carcass yield for tilapia was not influenced by the treatments. There was greater deposition of body protein in tilapia fed on diets with inclusion of DFCP, similarly to those with addition of DFL (Table 3). Total fat deposition was not affected by prebiotics, but it was higher for the lower level of inclusion $\left(2.5 \mathrm{~g} \mathrm{~kg}^{-1}\right)$.

Table 3. Carcass yield and nutrient deposition of Nile tilapia fingerlings fed on diets containing DFCP, DFL or Actigen 1.

\begin{tabular}{lccc}
\hline \multicolumn{1}{c}{ Factor/Variables $^{2}$} & CY $(\%)$ & TDCP $(g)$ & TDF $(\mathrm{g})$ \\
\hline Source $^{3}$ & & & \\
DFCP & $88.41 \pm 0.96$ & $8.68 \pm 0.61^{\mathrm{a}}$ & $5.31 \pm 0.44$ \\
DFL & $88.31 \pm 1.01$ & $8.54 \pm 0.71^{\mathrm{ab}}$ & $5.16 \pm 0.73$ \\
Actigen ${ }^{\mathrm{a}}$ & $88.39 \pm 1.12$ & $7.93 \pm 0.73^{\mathrm{b}}$ & $5.27 \pm 0.41$ \\
\hline${\text { Level }\left(\mathrm{g} \mathrm{kg}^{-1}\right)^{4}}_{2.5}$ & & \\
5 & $88.34 \pm 0.93$ & $8.50 \pm 0.90$ & $5.46 \pm 0.50^{\mathrm{a}}$ \\
\hline Source $x$ Level & $88.39 \pm 1.11$ & $8.26 \pm 0.53$ & $5.03 \pm 0.48^{\mathrm{b}}$ \\
\hline
\end{tabular}

${ }_{1}^{1}$ Values were expressed as mean \pm standard deviation. ${ }^{2}$ Variables - CY: carcass yield; TDCP: total deposited crude protein; TDF: total deposited fat. ${ }^{3}$ Means followed by different letters in the column, differ statistically by Duncan's test $(p<0.05) .{ }^{4}$ Means followed by different letters in the column, differ statistically by Student's t-test $(p<0.05)$. NS: nonsignificant $(p>0.05)$.

The digestive somatic index (DSI) was higher in the diet with inclusion of DFCP, a similar result to that of the diet with inclusion of the commercial prebiotic (Table 4). The effect of prebiotics on the hepatosomatic index (HSI) and the visceral fat index (VFI) was similar.

Table 4. Relative organ weights of Nile tilapia fingerlings fed on diets containing DFCP, DFL or Actigen® 1.

\begin{tabular}{llll}
\hline Factor/Variables $^{2}$ & $\mathrm{DSI}(\%)$ & $\mathrm{HSI}(\%)$ & $\mathrm{VFI}(\%)$ \\
\hline Source & & & \\
DFCP & & $2.38 \pm 0.27$ & $1.88 \pm 0.81$ \\
DFL & $3.45 \pm 0.70^{\mathrm{a}}$ & $2.40 \pm 0.59$ & $1.74 \pm 0.58$ \\
Actigen ${ }^{3}$ & $2.90 \pm 0.54^{\mathrm{b}}$ & $2.37 \pm 0.24$ & $1.83 \pm 0.88$ \\
\hline Level $^{\left(\mathrm{g} \mathrm{kg}^{-1}\right)}$ & $3.11 \pm 0.82^{\mathrm{ab}}$ & & \\
2.5 & & & $1.78 \pm 0.62$ \\
5 & $3.25 \pm 0.70$ & $2.43 \pm 0.35$ & $1.85 \pm 0.88$ \\
\hline Source $x$ Level & $3.05 \pm 0.74$ & $2.33 \pm 0.24$ & $\mathrm{NS}$ \\
\hline
\end{tabular}

${ }_{1}^{1}$ Values were expressed as mean \pm standard deviation. ${ }^{2}$ Variables - DSI: digestive somatic index; HSI: hepatosomatic index; VFI: visceral fat index. ${ }^{3}$ Means followed by different letters in the column, differ statistically by Duncan's test $(p<$ 0.05). NS: non-significant ( $p>0.05)$. 


\section{Metabolic parameters}

Higher concentrations of hepatic glycogen $(P=0.036)$ were found in the diets containing DFCP and Actigen $\AA$, with no difference between the tested levels (Table 5). For glucose and liver protein, there was no difference between the prebiotics, regardless of level of inclusion.

Table 5. Metabolic responses of Nile tilapia fingerlings fed on diets containing DFCP, DFL or Actigen $\AA^{1}$.

\begin{tabular}{lccc}
\hline \multicolumn{1}{c}{ Factor/Variables } & Glycogen $(\mathrm{mmol})$ & Glucose $(\mathrm{mmol})$ & Protein $(\mathrm{mg})$ \\
\hline Source & & & \\
DFCP & $4.25 \pm 0.51^{\mathrm{a}}$ & $55.61 \pm 8.16$ & $9.10 \pm 1.85$ \\
DFL & $3.66 \pm 0.76^{\mathrm{b}}$ & $48.70 \pm 7.44$ & $8.32 \pm 1.32$ \\
Actigen ${ }^{2}$ & $4.31 \pm 0.95^{\mathrm{a}}$ & $52.42 \pm 11.87$ & $8.62 \pm 1.58$ \\
\hline Level $\left(\mathrm{g} \mathrm{kg}^{-1}\right)$ & & & \\
2.5 & $4.00 \pm 0.74$ & $52.48 \pm 10.57$ & $8.86 \pm 1.39$ \\
5 & $4.15 \pm 0.87$ & $52.00 \pm 8.73$ & $8.50 \pm 1.80$ \\
\hline Source $x$ Level & $\mathrm{NS}$ & $\mathrm{NS}$ & $\mathrm{NS}$ \\
\hline
\end{tabular}

1 Values were expressed as mean \pm standard deviation. ${ }^{2}$ Means followed by different letters in the column, differ statistically by Duncan's test $(p<0.05)$. NS: non-significant $(p>0.05)$.

\section{DISCUSSION}

The results demonstrated that the action of the non-commercial prebiotics DFCP and DFL was equivalent to or higher than the prebiotic commercial as regards fish performance. The chemical composition and structural organization of the molecules contained in DFCP (predominantly $\alpha$-D-1,4-galacturonic acid) and in DFL (neutral arabinoxylan and acidic pectic-like material) are different from those reported for Actigen ${ }^{\circledR}$ (predominantly mannose). This suggests that the selectivity and degree of fermentability between these prebiotics may also be differentiated, reflecting directly on animal performance.

The promising effect of the lowest level $\left(2.5 \mathrm{~g} \mathrm{~kg}^{-1}\right)$ of inclusion shows that the appeal of the natural product and the lack of bioaccumulation risks in the food chain cannot be linked to excessive use of these ingredients in dietary supplements. Thus, it can be said that the widespread use of prebiotics is only possible if based on studies that establish reliable levels of inclusion in the diets. Overdosing can lead to adverse effects, such as gastrointestinal disorders, with consequent imbalance of microbial population and reduction of nutrient absorption, thus directly reflecting on weight gain and animal health [24]. By contrast, the ideal dose, which was shown to be the lowest in the present study, promotes beneficial effects combined with the lower cost of inclusion.

Ibrahem and coauthors [25] found satisfactory results for final weight with diets containing $5 \mathrm{~g} \mathrm{~kg}^{-1}$ of inclusion of inulin + vitamin C for Nile tilapia. In comparison, the inclusion of $20 \mathrm{~g} \mathrm{~kg}^{-1}$ of inulin did not have any effect on the growth of Psetta maxima larvae, when compared with supplementation with $20 \mathrm{~g} \mathrm{~kg}^{-1}$ of oligofructose [6]. Torrecillas and coauthors [8] reported that 10 and $20 \mathrm{~g} \mathrm{~kg}^{-1}$ of MOS did not produce significant changes in body composition of sea bass (Dicentrarchus labrax). In a study with rainbow trout, growth, feed efficiency and survival of the animals were better in the treatment containing $2 \mathrm{~g} \mathrm{~kg}^{-1}$ of MOS compared with treatments with a basal diet [7]. This information proves that the type of prebiotic, the level of inclusion and the study species are factors that directly influence the results.

As an adaptive strategy, the structure of the gastrointestinal tract of the fish may be changed in response to the composition of the diet, increasing the area of contact with food, increasing digestibility and maximizing the absorption of nutrients [26]. In the present study, the digestive somatic index (DSI) was higher in diets with inclusion of DFCP and Actigen $\AA$, indicating the possibility of an increase in the thickness of the gastrointestinal tract. In a study with larvae of black kingfish (Rachycentron canadum), prebiotics have improved the ultrastructure of the small intestine mucosa, interfering positively in the absorption of nutrients [27].

One of the metabolic effects of prebiotics is the generation of energy by means of fermentation, which serves as a substrate for the formation of short-chain fatty acids (SCFA). The amount of energy generated in this process is variable and depends on the structure and degree of fermentation of the fiber. In the present study, the levels of liver glycogen were higher in diets containing DFCP and Actigen $₫$ (Table 3), which can be explained by the less complex chemical structure of these fibers when compared with the structure of DFL. In this case, the fermentability of diets containing DFL is slower; energy is gradually made available, and there is less storage of surplus energy in the form of glycogen. 
Although fish fed on diets containing DFL have a lower reserve of glycogen, they did not differ from those fed with inclusion of DFCP for final body weight, protein deposition and body fat deposition. Previous studies have reported that products of the fermentability of some types of prebiotics can interfere with the production of growth and reproduction hormones [28]. DFL may have interfered with hormonal response, because the grain of linseed has compounds such as lignans, which can interfere in hormone metabolism of the host, when fermented [29].

\section{CONCLUSION}

The results of the present study lead to the conclusion that the action of non-commercial prebiotics DFCP and DFL is equivalent to, or greater than, the commercial prebiotic (Actigen ${ }^{\circledR}$ ) on the growth of Nile tilapia. This finding confirms the possibility of obtaining and using new prebiotics, thus expanding the options for ecofriendly additives for fish nutrition.

Funding: This research received no external funding.

Acknowledgements: The authors are grateful to the National Council for Scientific and Technological Development (CNPq) for the grant of Research Productivity (Leila Picolli da Silva), to the Coordination for the Improvement of Higher Education Personnel (CAPES) for the Masters scholarship (Patricia Agnes Mombach), and to companies Alltech ${ }^{\circledR}$, Agropecuária Giruá and Giovelli \& Cia Ltda for the donation of ingredients.

Conflicts of Interest: The authors declare no conflict of interest.

\section{REFERENCES}

1. FAO. The State of World Fisheries and Aquaculture: Opportunities and challenges. FAO Fisheries and Aquaculture Departament, Food and Agriculture Organization of the United Nations, Rome, 2014.

2. Regulation (EC) No 1831/2003 of the European Parliament and of the Council of 22 September 2003 on additives for use in animal nutrition (Text with EEA relevance). http://irmm.jrc.ec.europa. eu/SiteCollectionDocuments/EC1831-2003.pdf

3. Ringo E, Olsen RE, Gifstad TO, Dalmo RA, Amlund H, Hemre G-I, Bakke AM. Prebiotics in aquaculture: a review. Aquacult Nutr. 2010;16:117-136.

4. Dimitroglou A, Reynolds P, Ravnoy B, Johnsen F, Sweetman JW, Johan Johansen J, Davies SJ. The effect of mannan oligosaccharide supplementation on atlantic salmon smolts (Salmo salar l.) fed diets with high levels of plant proteins. J Aquac Res Development. 2011; S1:011.

5. Gibson GR, Roberfroid MB. Dietary modulation of the humam colonie microbiota: introducing the concept of prebiotics. J Nutr. 1995;125:1401-1412.

6. Mahious AS, Gatesoupe FJ, Hervi M, Metailler R, Ollevier F. Efffect of dietary inulin and oligosaccharides as prebiotics for weaning turbot, Psetta máxima (Linnaeus, C. 1758). Aquac Int. 2006;14:219-229.

7. Staykov Y, Spring P, Denev S, Sweetman J. Effect of a mannan oligosaccharide on the growth performance and immune status of rainbow trout (Oncorhynchus mykiss). Aquacult Int. 2007;15:153-161.

8. Torrecillas S, Makol A, Caballero MJ, Montero D, Robaina L, Real FJ, Sweetman J, Tort L, Izquierdo, M.S. Immune stimulation and improved infection resistance in European sea bass (Dicentrarchus labrax) fed mannan oligosaccharides. Fish Shellfish Immunol. 2007;23:969-981.

9. Burr G, Hume M, Neill WH, Gatlin DM. Effects of prebiotics on nutrient digestibility of soybean-meal-based diets by red drum (Sciaenops ocellatus). Aquac Res. 2008;39:1680-1686.

10. Grisdale-Helland B, Helland SJ, Gatlin DM. The effects of dietary supplementation with mannanoligosaccharide, fructooligosaccharide or galactooligosaccharide on the growth and feed utilization of Atlantic salmon (Salmo salar). Aquacult. 2008;283:163-167.

11. Mohnen D. Pectin structure and biosynthesis. Curr Opin Plant Biol. 2008;11:266-277.

12. Tamura $\mathrm{C}$, Nakauma M, Furusawa H, Kadota T, Kamata $\mathrm{Y}$, Nishijima M, Itoh S, Sugita-Konishi $Y$. Formulation of a pectin gel that efficiently traps mycotoxin deoxynivalenol and reduces its bioavailability. Carbohydr Polym. 2013;93:747-752.

13. Cui W, Mama G, Biliaderis CG. Chemical structure, molecular size distributions, and rheological properties of flaxseed gum. J Agric Food Chem. 1994;42:1891-1895.

14. Rebolé A, Rodríguez ML, Ortiz LT, Alzueta C, Centeno C, Treviño J. Mucilage in linseed: effects on the intestinal viscosity and nutrient digestion in broiler chicks. J Sci Food Agric. 2002;82:1171-1176.

15. Calliari CM. Pectina cítrica: extração e propriedades tecnológicas. 1. ed. Berlim: Novas Edições Acadêmicas, 2015, $66 \mathrm{p}$. 
16. Goulart FR, Speroni CS, Lovatto NM, Loureiro BB, Corrêia V, Radünz Neto J, Silva LP. Atividade de enzimas digestivas e parâmetros de crescimento de juvenis de jundiá (Rhamdia quelen) alimentados com farelo de linhaça in natura e demucilada. Semina Cien Agrar. 2013;34:3069-3080.

17. Furuya WM. (ed.). Tabelas brasileiras para a nutrição de tilápias. Toledo: GFM, 2010. 100 p.

18. Meyer G, Fracalossi DM, Borba MR. A importância da quantidade de energia na ração de peixes. Pan Aquicult. 2004;14:53-57.

19. AOAC. Official Methods of Analyses of the Association of Official Analytical Chemists International, 16th edn. In: Association of official analytical chemists, Supplement 1998, Washington, 1995.

20. Bligh EG, Dyer WJ. Rapid method of total lipid extraction and purification. Canadian. J Biochem Physiol. 1959,37:911-917.

21. Fracalossi DM, Rodrigues APO, Castro TS, Cyrino JEP. Técnicas experimentais em nutrição de peixes. In: Fracalossi DM, Cyrino JEP (Eds.), Nutriaqua: nutrição e alimentação de espécies de interesse para a aquicultura brasileira. Copiart, Florianópolis. 2012:37-63.

22. Bradford MM. A rapid and sensitive method for the quantitation of microgram quantities of protein utilizing the principle of protein-dye binding. Anal Biochem. 1976;72:248-254.

23. Park JT, Johnson MJ. A submicro determination of glucose. J Biol Chem. 1949;181:149-151.

24. Medeiros LB, Carrijo AS, Negrini JM. Utilização de prebiótico na alimentação de filhotes de papagaio verdadeiro (Amazona aestiva) em processo de reabilitação. Arch Vet Sci. 2006;11:62-68.

25. Ibrahem MD, Fathi M, Mesalhy S, Abd El-Aty, A.M. Effect of dietary supplementation of inulin and vitamin $\mathrm{C}$ on the growth, hematology, innate immunity, and resistance of Nile tilápia (Oreochromis niloticus). Fish Shellfish Immunol. 2010;29:241-246.

26. Leenhouwers JI, Adjei-Boateng D, Verreth JAJ, Schrama JW. Digesta viscosity, nutrient digestibility and organ weights in african catfish (Clarias gariepinus) fed diets supplemented with different levels of a soluble non-starch polysaccharide. Aquacult Nutr. 2006;12:111-116.

27. Salze G, McLean E, Schwarz MH, Craig SR. Dietary mannan oligosaccharide enhances salinity tolerance and gut development of larval cobia. Aquacult. 2008;274:148-152.

28. Cordeiro R, Fernandes PL, Barbosa LA. Semente de linhaça e o efeito de seus compostos sobre as células mamárias. Braz J Pharmacog. 2009;19:727-732.

29. Cupersmid L, Fraga APR, Abreu ES, Rosier IOP. Linhaça: composição química e efeitos biológicos. e-Sci. 2012,5,33-40.

(C) 2020 by the authors. Submitted for possible open access publication under the terms and conditions of the Creative Commons Attribution (CC BY NC) license (https://creativecommons.org/licenses/by-nc/4.0/). 